\title{
Is the cost the primary barrier for cataract surgery in Paraguay?
}

\section{A taxa para a cirurgia é a principal barreira para a adesão à cirurgia de catarata no Paraguai?}

Harumi G. Burga ${ }^{1}$, Celeste N. Hinds ${ }^{1}$, Van C. Lansingh ${ }^{1,2}$, Margarita Samudio ${ }^{3}$, Susan Lewallen ${ }^{4,5}$, Paul Courtright ${ }^{4,5}$, Rainald Duerksen ${ }^{1}$, Pablo Cibils $^{1}$, Manuel Zegarra ${ }^{1}$

\begin{abstract}
Purpose: To determine if the cost was the main barrier to undergo cataract surgery in Paraguay.

Methods: We conducted a cohort study with patients screened in the 2011 Rapid Assessment of Avoidable Blindness (RAAB) who had reported that the cost was the main barrier to undergo cataract surgery in Paraguay. All patients with operable cataract from the RAAB study and with registered telephone numbers were interviewed by telephone and were offered free surgery services. The patients who did not come for surgery were re-interviewed by telephone to analyze the reasons for not undergoing the operation.

Results: Out of 122 patients identified in the RAAB study with barriers for cataract surgery, 69 (56.6\%) reported that the surgical fee was the main barrier; 52 (75.4\%) of them had their telephone numbers registered. Thirty-six (69.2\%) patients did not reside in the metropolitan area of Asunción. Six patients (12\%), all from Asunción, agreed to undergo free surgery. Forty-six patients did not agree the free surgery mainly due to the costs associated with their transportation $(n=31,67 \%)$ and the travel costs of their companion ( $n=6,13 \%)$.

Conclusion: Surgery fee alone was not the major contributing factor for not undergoing cataract surgery. Place of residence and other indirect out-of-pocket expenses, such as transportation and companion-related costs appear to be more relevant. While further investigation is needed to assess if reducing the cost of transport will improve the uptake, the findings in this study suggest that a surgical package with all costs should be offered to patients of cataract surgical programs to increase cataract surgical coverage in Paraguay.
\end{abstract}

Keywords: Cataract extraction/statistics and numerical data; Costs and cost analysis; Health services accessibility; Paraguay

\section{RESUMO}

Objetivo: Determinar se a taxa de cirurgia é a principal barreira para a adesão à cirurgia de catarata no Paraguai.

Métodos: Foi realizado um estudo de coorte com pacientes identificados na Avaliação Rápida da Cegueira Evitável (RAAB) de 2011, que haviam informado ser a taxa para a cirurgia a principal barreira para se submeter à cirurgia de catarata no Paraguai. Todos os pacientes com catarata operável a partir do estudo RAAB, cujos números de telefone foram registrados, foram entrevistados por telefone e foi oferecida a cirurgia gratuitamente. Aqueles pacientes que não compareceram para a cirurgia foram então re-entrevistados por telefone para confirmar as suas razões para não fazer a cirurgia. Resultados: Das 122 pessoas identificadas no estudo RAAB com barreiras para a cirurgia de catarata, $69(56,6 \%)$ relataram a taxa cirúrgica como a principal barreira para a cirurgia; $52(75,4 \%)$ destes individuos tiveram seus números de telefone registrados. Trinta e seis $(69,2 \%)$ pacientes não residiam na área metropolitana de Assunção. Seis pacientes (12\%) aceitaram se submeter à cirurgia gratuita, todos eles de Assunção. Dos 46 pacientes que não aceitaram a cirurgia gratuita, as duas principais razões para o não comparecimento foi o custo de transporte $(n=31,67 \%)$ e os custos de viagem de seu companheiro ( $n=6,13 \%)$.

Conclusão: A taxa de cirurgia de catarata per se não foi a barreira principal. Local de residência e outras despesas pessoais indiretas, como transporte e custos relacionados à companhia parecem ser mais relevantes. Embora mais estudos sejam necessários para avaliar se a redução do custo do transporte vai melhorar a adesão, os resultados sugerem que um pacote cirúrgico que inclua todos os custos deve ser oferecido aos pacientes dos programas de cirurgia de catarata a fim de aumentar a cobertura da cirurgia de catarata no Paraguai.

Descritores: Extração de cataratalestatística \& dados numéricos; Custos e análise de custos; Acesso aos serviços de saúde; Paraguai

\section{INTRODUCTION}

The World Health Organization (WHO) recently estimated that over 280 million of the global population is visually impaired and 39 million of them are blind. Eighty-two percent of the blind and $65 \%$ of the visually impaired are aged 50 and above ${ }^{(1)}$. In Americas, approximately 3.2 million people are blind and 26.6 million people are visually impaired ${ }^{(2)}$

Cataract is responsible for $33 \%$ of the visual impairment worldwide and is the single most important cause of blindness affecting $51 \%$ of the global population. Surveys in Latin America and the Caribbean show that cataract is the leading cause of blindness and visual impairment, with $47 \%-87 \%$ of individuals bilaterally blinded ${ }^{(3,4)}$.

The cataract surgical rate (CSR), the number of cataract operations performed per year per million population, though is often associated with the socio-economic development of the country, this is not always true, especially in countries such as India and China ${ }^{(5-7)}$. Across Latin America, the CSR ranges from approximately 900-6,000, with an average of $2,672^{(8)}$.

Despite significant developments in the region, unless the regional CSR increases considerably, the VISION 2020 goal of eliminating avoidable vision loss by cataract will not be met. In developed countries in the region,the visual impairment due to cataract is not a major issue; however, for developing countries in the region increasing CSRs remains a challenge due to several factors such as affordability, place of residence, and difficult-to-reach communities with poor access to information and services ${ }^{(5)}$. Surgical fees are often reported as barrier to undergo cataract surgery ${ }^{(9)}$. However, some studies have suggested that fear of surgery and a low perceived need for better 
sight contribute more significantly. Even when free surgical services are offered, there can be a lack of demand and low utilization ${ }^{(9-11)}$.

In 2011, a Rapid Assessment of Avoidable Blindness (RAAB) survey was conducted in Paraguay to follow up the RAACS (Rapid Assessment of Cataract Surgical Services) survey conducted in 2000. The RAAB survey showed that cataract was the main cause of blindness (43.8\%) and severe visual impairment (40.5\%). The results of the study indicated an impressive reduction in the prevalence of blindness from 3.0\% to $1.1 \%$ among the people of age 50 years and above; cataract surgical coverage (at<6/60) increased from $36 \%$ to $78 \%$ and good quality outcomes of cataract surgeries increased from $64 \%$ to $90 \%{ }^{(12,13)}$. These results suggest that cataract is now better managed in Paraguay.

We sought to determine if the fee is the main barrier to undertake cataract surgery in Paraguay.

\section{METHODS}

In October and November, 2011, a Rapid Assessment of Avoidable Blindness (RAAB) national survey was undertaken in Paraguay ${ }^{(12)}$. The RAAB study was conducted by five third year ophthalmology residents, supervised by a senior ophthalmologist. All patients identified in the RAAB with a visual acuity (VA) $<6 / 18$ attributed to cataract in one or both eyes and judged to have an operable cataract. The patients, who reported that surgical fee was the main barrier to undergo cataract surgery, were selected for the study. Patients with incomplete forms, $(n=13)$ and those who refused to respond to the questionnaire $(n=4)$ were excluded from the study.

All patients were contacted by phone by a trained social worker. The questionnaire was designed to investigate if the fee for cataract surgery was a barrier to undergo the surgery. Questions were asked to reconfirm demographic data, the indication of cataract surgery, and the issues regarding fees. As part of the study protocol, the social worker then offered the patient cataract surgery free of charge. The free surgeries were to be conducted during the cataract surgical campaign in Fundación Vision's central clinic located in Asunción, Paraguay and were scheduled to take place within the next two weeks following the interview. Transportation costs to and from their residence and accommodation were not provided with the free cataract surgery.

One week after the end of the surgical campaign the patients who did not attend the free surgery were contacted and re-interviewed by telephone to establish the reasons for failure to attend. An open ended quasi-structured questionnaire was used to solicit the responses.

We first analyzed the differences between the people with and without phone numbers. We next determined the proportion of those who took advantage of the free surgery service (and factors associated with acceptance). Finally, we assessed the reasons to opt out of the free surgery service. Comparisons were made based on sex, age, province, and pre-operative VA. Data were entered in an Excel 6.0 spreadsheet and subsequently analyzed by SPSS 11.5 (Chicago, IL) for Windows. Descriptive statistics for socio-demographic characteristics and causes of nonattendance to cataract surgery nominal variables were expressed as percentage.

The study was approved by the Investigation and the Medical Ethics Committee of Fundación Vision, and was performed in accordance with the ethical standards laid down in the 1964 Declaration of Helsinki. All patients signed a consent form prior to their inclusion in the RAAB.

\section{RESULTS}

From the RAAB survey, among the 2,862 persons studied, 54 people had a bilateral cataract surgery and 75 people had undergone unilateral cataract surgery. For this study, 122 people had operable cataract with presenting vision of $<6 / 18$ in one or both eyes and qualified the study parameters. The study population included 4 people who underwent a cataract surgery in one eye and visually impairing cataract in the other eye. Among the 122 people, 69 (56.6\%) reported that the fee for surgery was the main barrier to undergo cataract surgery. Other reasons included, fear $(n=22)$, lack of desire to have surgery $(n=9)$, difficulty accessing surgical facilities $(n=7)$, and other reasons $(n=15)$. Of the 69 people, $52(75.4 \%)$ had a valid registered telephone number. Of these, 37 (63.45) had unilateral cataract with normal vision or vision loss due to other conditions such as refractive error in the other eye. People with registered phone numbers were slightly younger than those without phone numbers (Table 1).

After the phone interviews surgical campaign was conducted for two weeks and offered free cataract surgery to the patients; only 6 out of the 52 people enrolled in the study (12\%) attended the clinic in Asunción for surgery and all were from the metropolitan area of Asunción (Table 2).

The people who did not take advantage of the free cataract surgery were contacted by telephone after one week after the surgical campaign. While 31 people (67\%) had reported that the cost of transportation was the reason for not coming for the surgery, 6 people (13\%) reported that the cost of transportation of their companion was the reason. Nine people (20\%) mentioned other causes such as difficulty traveling, other medical conditions, or poor weather conditions. Although the numbers are small, uptake was highest among those who underwent a previous cataract surgery (50\% uptake), followed by those who had bilateral cataracts, (3/19) and finally those with unilateral cataract (1/28).

\begin{tabular}{|c|c|c|c|}
\hline Patient characteristics & $\begin{array}{l}\text { Telephone number registered ( } n=52) \\
\qquad(\%)\end{array}$ & $\begin{array}{l}\text { No telephone number }(n=17) \\
\qquad N(\%)\end{array}$ & $\begin{array}{c}\text { Odds ratio }(95 \% \mathrm{Cl}) \\
\text { p value }\end{array}$ \\
\hline Average age (SD) & $71.6 \pm 11.0$ & $78.8 \pm 8.9$ & $p=0.02$ \\
\hline \multicolumn{4}{|l|}{ Sex } \\
\hline Males & $22(42.3)$ & $9(52.9)$ & $0.65(0.22-1.96)$ \\
\hline Females & $30(57.7)$ & $8(47.1)$ & $p=0.62$ \\
\hline \multicolumn{4}{|l|}{ Residence } \\
\hline Metropolitan & $16(30.8)$ & $5(29.4)$ & $1.07(0.32-3.53)$ \\
\hline Outside metro & $36(69.2)$ & $12(70.6)$ & $p=0.84$ \\
\hline \multicolumn{4}{|c|}{ Visual acuity of eye to be operated } \\
\hline $6 / 18$ & $32(61.5)$ & $10(58.8)$ & 1.0 (reference) \\
\hline$<6 / 18$ to $6 / 60$ & $13(25.0)$ & $4(23.5)$ & $1.02(0.27-3.83)$ \\
\hline$<6 / 60$ to $3 / 60$ & $4(7.7)$ & $1(5.9)$ & $0.73(0.07-3.21)$ \\
\hline$<3 / 60$ & $3(5.7)$ & $2(11.7)$ & \\
\hline
\end{tabular}

* $=$ odds ratio includes $<6 / 60$ to $3 / 60$ and $<3 / 60$. 
Table 2. Characteristics of people with cataract who attended the free cataract program

\begin{tabular}{|c|c|c|c|}
\hline Characteristic & $\begin{array}{l}\text { Attended free cataract surgery } n=6 \\
\qquad N(\%)\end{array}$ & $\begin{array}{l}\text { Did not attend free cataract surgery } n=46 \\
\qquad N(\%)\end{array}$ & $\begin{array}{l}\text { Odds ratio }(95 \% \mathrm{Cl}) \\
\text { p value }\end{array}$ \\
\hline \multicolumn{4}{|l|}{ Sex } \\
\hline Females & $4(13.8)$ & $25(86.2)$ & $1.68(0.28-10.10)$ \\
\hline Males & $2(9.0)$ & $21(91.0)$ & $p=0.89$ \\
\hline \multicolumn{4}{|l|}{ Age $^{*}$} \\
\hline 50-59 years & $0(0.0)$ & $9(100.0)$ & 1.0 (reference) \\
\hline $60-69$ years & $1(11.1)$ & $8(88.9)$ & $2.22(0.17-28.86)$ \\
\hline 70-79 years & $3(12.0)$ & $22(88.0)$ & $1.74(0.17-17.59)$ \\
\hline 80-89 years & $2(40.0)$ & $3(60.0)$ & $7.50(0.59-95.38)$ \\
\hline$\geq 90$ years & $0(0.0)$ & $4(100.0)$ & $2.00(0.10-39.08)$ \\
\hline Average age (SD) & $69.8( \pm 11.1)$ & $72.0( \pm 11.0)$ & $p=0.22$ \\
\hline \multicolumn{4}{|l|}{ Residence* } \\
\hline Metropolitan & $6(37.5)$ & $10(62.5)$ & $23.55(2.61-212.67)$ \\
\hline Outside metro & $0(0.0)$ & $36(100.0)$ & $p=0.001$ \\
\hline \multicolumn{4}{|l|}{ Visual acuity of eye to be operated } \\
\hline $6 / 18+$ & $2(33.3)$ & $30(65.2)$ & 1.0 (reference) \\
\hline$<6 / 18$ to $6 / 60$ & $3(50.0)$ & $10(21.7)$ & $4.50(0.66-30.91)$ \\
\hline$<6 / 60$ to $3 / 60$ & $1(16.6)$ & $3(6.5)$ & $2.50(0.19-32.20)^{* *}$ \\
\hline$<3 / 60$ & $0(0.0)$ & $3(6.5)$ & \\
\hline \multicolumn{4}{|l|}{ Visual acuity in the better eye* } \\
\hline $6 / 18+$ & $4(66.6)$ & $11(23.9)$ & 1.0 (reference) \\
\hline$<6 / 18$ to $6 / 60$ & $2(33.3)$ & $21(45.6)$ & $0.26(0.04-1.66)$ \\
\hline$<6 / 60$ to $3 / 60$ & $0(0.0)$ & $8(17.3)$ & $0.16(0.02-1.56)^{* *}$ \\
\hline$<3 / 60$ & $0(0.0)$ & $6(13.0)$ & \\
\hline \multicolumn{4}{|l|}{ Previous cataract surgery } \\
\hline $\begin{array}{l}\text { No cataract surgery received } \\
\text { (unilateral cataract) }\end{array}$ & $1(16.6)$ & $28(60.8)$ & (reference) \\
\hline $\begin{array}{l}\text { Cataract surgery in one eye (cataract } \\
\text { causing vision loss in the second eye) }\end{array}$ & $2(33.3)$ & $2(4.3)$ & $28.0(1.71-458.8) p=0.04$ \\
\hline $\begin{array}{l}\text { No cataract surgery received } \\
\text { (bilateral cataract) }\end{array}$ & $3(50.0)$ & $16(34.7)$ & $5.25(0.50-54.78) p=0.33$ \\
\hline
\end{tabular}

${ }^{*}=$ note in cases with 0 is one or more cells, 1 has been added to each cell to calculate an estimated odds ratio and $95 \%$ Cl; ${ }^{* *}=0$ odds ratio includes $<6 / 60$ to $3 / 60$ and $<3 / 60$.

\section{DISCUSSION}

In most cases one can infer that free surgery would provide increase access to patients who would not otherwise consider it; however, there are always other complex factors involved in the decision to undergo cataract surgery ${ }^{(14,15)}$

Lack of awareness, poor quality service, cost of surgery and cultural beliefs, distance to service, lack of escort, and fear are some of major barriers between cataract patients and service providers resulting in a low uptake in the presence of adequate service availability ${ }^{(15,16)}$.

There were slightly more women in our study compared to men; however, this reflects the underlying prevalence of cataract in the population. The average age of people accepting the surgery was slightly younger than those not accepting the surgery, consistent with studies in other settings ${ }^{(17)}$

The most important factor toward acceptance was residence; while one in three cataract patients living in Asunción accepted surgery, none of those living outside of Asunción traveled to the capital for surgery.

Some studies reported that the surgical fee is the single most important barrier to cataract surgery uptake ${ }^{(18,19)}$. If surgical fee is above the affordable limits of the individual or family, this can be a significant barrier. However, it should be recognized that families make financial decisions regarding surgery based upon the total anticipated costs associated with the surgery. Besides the surgical fee, these costs include additional medications, transport to and from the surgical facility, food at the surgical facility, transport and accommodation expenses of the escort, and loss of income during the surgery and recovery ${ }^{(6,19-21)}$.

In our setting the offer to waive the fee for the surgery (approximately PGY1, 500,000 /US\$334) (not including transportation, accommodation or medication) resulted in a low uptake (12\%), only comprising those living in the same metropolitan area as the surgical facility. Further only one-third of the population living in the city accepted the surgery.

Our results are consistent with findings from Kenya, Bangladesh, and the Philippines ${ }^{(22)}$, where free cataract surgery was offered and only $30 \%$ of cases attended. In Nepal, where both transportation and free surgery were offered, the utilization rate was still below $60 \%{ }^{(23)}$. Similarly, in Tanzania when surgery and transportation services were offered to those reporting the surgical fee as the primary barrier to surgery, only a small proportion had accepted ${ }^{(14)}$. In the Tanzanian setting it was recognized that reporting "too poor to pay" was a convenient response that did not actually reflect reality. While our findings are similar to the Tanzanian study, since free transport was not offered in Paraguay it cannot be claimed that offer of free transport would increase the uptake of surgery. The average cost of transportation 
from the most rural areas of Paraguay to Asunción and back via public transport (bus) is approximately PGY 80,000/US\$20, while accommodation per night per person in moderate lodgings costs about PGY100,000/US\$25. Fundación Vision offers lodging at its central at a cost of PGY 50,000 for both the patient and the companion. Free transport offer to many of these patients may not result in a significant uptake of cataract surgery.

Some studies have highlighted the link between acceptance and lack of information or awareness of the disease and its treatment $t^{(6,22)}$. However, it should be noted that in our setting, all the people with cataract enrolled in the study were provided information twice: during the RAAB survey and during the phone interviews. Thus, it is unlikely that lack of information is a contributing factor in the decision to not to seek surgery.

While visual needs differ from person to person it may be surmised that people with the most reduced vision would more likely opt for surgery. Evidence in other settings suggests just the opposite. In the Tanzanian setting people with better pre-operative vision were more likely to come for surgery. The more elderly and visually disabled did not seek surgery or were not supported by the family to seek surgery ${ }^{(24)}$. None of the 14 people, 3 from the metropolitan area, with a best eye vision of $<20 / 200$ accepted surgery, similar to the Tanzanian setting. People with unilateral cataract may not seek care if only one eye is affected; however, once having had the surgery, it appears that patients are keen to have the second eye operated. Perceptions of vision needs can change with a successful operation ${ }^{(14,25)}$. Studies have noted that patients who had undergone a cataract surgery in one eye with a good post-operative vision were more inclined to accept surgery for the second eye as compared with those with poor outcomes, highlighting the impact of postoperative visual acuity on decision making ${ }^{(6,25)}$.

There are several aspects of this study which limit interpretations of findings. Although the study was nationwide, the number of study participants was limited, making it difficult to assess factors associated with uptake. Few of our patients were blind per WHO definition from cataract. Further, while participants who did not have a telephone number did not differ significantly with regard to age, sex, and visual acuity of those with a telephone number. It is likely that those without a telephone are poorer. The two weeks of free surgery campaign time may be too short for people to adequately prepare and travel for the surgery. As noted above, we cannot infer with certainty from our findings that transport is the primary barrier to accept the surgery among this group. By offering free transport and assessing the uptake we can further understand the contribution of transport to undertake the surgery.

In Latin America there is a large gap between the target CSRs to operate on all eyes with $V A<6 / 18$ with the regional CSR being $1,425^{(15,26,27)}$. Resent analysis in 2012 show that the current CSR in the Latin American region at 2,672 per million with Paraguay at 1,539 indicating that lot needs to be done to address the multiple factors influencing the uptake of cataract surgery ${ }^{(5,8)}$.

Our findings suggest that the direct fee for surgery is not the important contributing factor in cataract surgery services in Paraguay. Similar to Ethiopia, indirect costs such as transportation, accommodation for both the patient and his/her companion, and medication may play a more significant role in service uptake even if surgery fee is completely waived ${ }^{(28)}$.

Future work in Paraguay may need to focus on assisting ophthalmologists to work in rural areas of the country as well as conducting more outreach in which surgeries are done in distant surgical facilities. Programmes should consider "packaging" transportation to and from the clinics, accommodation, and medicines to reduce indirect costs. The use of low cost mobile clinical and surgical services may also be an additional approach to improve access to cataract surgical services. That being said, further investigation is needed to clarify if free transportation improves the uptake.

\section{REFERENCES}

1. Pascolini D, Mariotti SP. Global estimates of visual impairment: 2010. Br J Ophthalmol. 2012;96:614-8

2. Global data on visual impairment 2010. WHO. [on-line] 2013 [cited 2013 July 13]. Available at: http://www.who.int/blindness/GLOBALDATAFINALforweb.pdf

3. Furtado JM, Lansingh VC, Carter MJ, et al. Causes of blindness and visual impairment in Latin America. Surv Ophthalmol. 2012;57:149-77.

4. Limburg H, Barria von-Bischhoffshausen F, Gomez P, Silva JC, Foster A. Review of recent surveys on blindness and visual impairment in Latin America. Br J Ophthalmol. 2008;92:315-9.

5. Lansingh VC, Resnikoff S, Tingley-Kelley K, et al. Cataract surgery rates in Latin America: a four-year longitudinal study of 19 countries. Ophthalmic Epidemiol. 2010;17: 75-81.

6. Yin $Q, H u A$, Liang $Y$, et al. A two-site, population based study of barriers to cataract surgery in rural China. Invest Ophthalmol Vis Sci. 2009:50:1069-75.

7. Murthy GVS, Gupta SK, John N, Vashist P. The current status of cataract blindness and Vision 2020: The right to sight initiative. Indian Journal of Ophthalmology. 2008;56:489.

8. VISION 2020 Latin America. Table 1. Cataract surgery rate (per million) and number of ophthalmologists (per million population) for Latin America countries. [on-line] 2013 [cited 2013 December 1]. Available at: http://www.v2020la.org/images/CSR_2012.pdf.

9. Briessen S, Geneau R, Roberts H, Opiyo J, Courtright P. Understanding why cataract patients refuse free surgery: the influence of rumors in Kenya. Trop Med Int Health. 2010;15:534-9.

10. Lewallen S, Bronsard A, Paul I, Courtright P. The social and family dynamics behind the uptake of cataract surgery: findings from Kilimanjaro Region, Tanzania. $\mathrm{Br} J$ Ophthalmol. 2005;89:1399-402.

11. Limburg H, Silva JC. RACSS - Encuesta Rápida de los Servicios de Cirugía de Catarata RAAB - Encuesta Rápida de Ceguera Evitable. Manual de Ceguera por Catarata América Latina, 1era edición. 2011. Capítulo V; Imagen \& Diseño Producciones Ltda, Bogotá Colombia. p.39-41.

12. Duerksen R, Limburg H, Carron JE, Foster A. Cataract blindness in Paraguay - results of a national survey. Ophthalmic Epidemiol. 2003;10:349-57.

13. Duerksen R, Limburg H, Lansingh V C, Silva J C. Review of Blindness and Visual Impairment in Paraguay: Changes between 1999 and 2011. Ophthalmic Epidemiology. 2013:20:301-7.

14. Kessy J P, Lewallen S. Poverty as a barrier to accessing cataract surgery: a study from Tanzania. Br J Ophthalmol. 2007;91:1114-6.

15. World Health Organization, Cost effectiveness thresholds. Retrieved. From [on-line] 2013 [cited 2013 July 20]. Available at: http://www.who.int/choice/costs/CER_thresholds/en/ index.html

16. Brilliant GE, Lepkowski JM, Zurita B, Thulasiraj RD. On behalf of the Operations Research Group. Social determinants of cataract surgery utilization in South India. Arch Ophthalmol. 1991;109:584-9.

17. Congdon N, Zhang M, Gao Y, Griffiths S, Lam DS, Huang Y, Lam J, Li L, Wang G, Wu X. Understanding barriers to cataract surgery among older persons in rural China through focus groups. Ophthalmic Epidemiol. 2011;18:179-86.

18. Briesen S, Roberts H, Ilako D, Karimurio J \& Courtright P. Are blind people more likely to accept free cataract surgery? A study of vision-related quality of life and visual acuity in Kenya. Ophthalmic Epidemiol. 2010;17:41-9.

19. Mehari ZA, Zewedu RT, Gulilat FB. Barriers to cataract surgical uptake in central Ethiopia. Middle East Afr J Ophthalmol. 2013;20:229-33.

20. Yorston D, Abiose A. Cataract blindness - the African perspective. Bull World Health Organ. 2001;79:257.

21. Limburg H, Kumar R. Follow up study of blindness attributed to cataract in Karnataka State, India. Ophthalmic Epidemiol. 1998;5:211-23.

22. Eusebio C, Foster A. Kuper H, Mamunur AK, et al. Predictors of attendance and barriers to cataract surgery in Kenya, Bangladesh and the Philippines. Disabil Rehabil. 2013; 35(19):1660-7.

23. Snellingen T, Shrestha BR, Gharti MP, Shrestha JK, Upadhyay MP, Pokhrel RP. Socioeconomic barriers to cataract surgery in Nepal: the South Asian cataract management study. Br J Ophthalmol. 1998;82:1424-8

24. Chibuga E, Massae P, Geneau R, Mahande M, Lewallen S, Courtright P. Acceptance of cataract surgery in a cohort of Tanzanians with operable cataract. Eye. 2008:22:830-3.

25. Fang J, Wang X, Lin Z, Yan J, Yang Y, Li J. Variation of cataract surgery cost in four different graded providers of China. BMC Public Health. 2010;10:543.

26. Bettadapura G, Datti N, Donthi K, et al. Barriers to the uptake of cataract surgery in a rural population of south Karnataka, India. IJCRR. 2013;5:12

27. Lewallen S, Perez-Straziota C, Lansingh V, MD, Limburg H, Silva JC. Variation in cataract surgery needs in Latin America. Arch Ophthalmol. 2012;130:1575-8

28. Melese M, Alemayehu W, Friedlander E, Courtright P. Indirect costs associated with accessing eye care services as a barrier to service use in Ethiopia. Trop Med Int Health. 2004;9:426-31. 